\title{
KETERBUKAAN KEUANGAN PARTAI POLITIK TERHADAP PRAKTIK PENCUCIAN UANG DARI HASIL TINDAK PIDANA KORUPSI*
}

\author{
Laurensius Arliman S \\ Sekolah Tinggi Ilmu Hukum (STIH) Padang \\ Jl. Gang Mesjid Baiturahman No. 40 Padang \\ E-mail: laurensiusarliman@gmail.com
}

DOI: $\underline{10.15408 / j c h . v 4 i 2.3433}$

\begin{abstract}
Elections means implementation of the sovereignty of the people held in directly, general, free, confidential, honest, and fair in the Republic of Indonesia under Pancasila and the Constitution of the Republic of Indonesia Year 1945. The implementation of the election has a lot of dynamics, among others political boat fees are expensive, expensive campaign funds to political imagery, the cost of consultations and surveys are expensive as well as winning money politics. Financial disclosure is very important political party in an election, because a lot of the flow of the corruption that is used in the election. As a result, people do not believe in political parties, or some communities in Indonesia began to no longer sympathetic to the political party. The idea of political party financial disclosure regulations should be initiated carefully in Indonesian election codification plan. Forward Indonesia must have arrangements campaign funds or political funds transparent, accountable, and has strict sanctions and binding on the parties involved, so that people come back believing again to political parties, and assured political parties place to channel their aspirations in granting the right in elections.

Keywords: Finance; Political parties; Corruption
\end{abstract}

Abstrak: Pemilu adalah sarana pelaksanaan kedaulatan rakyat yang diselenggarakan secara lansung, umum, bebas, rahasia, jujur, dan adil di dalam Negara Kesatuan Republik Indonesia berdasarkan Pancasila dan Undang-Undang Dasar Negara Republik Indonesia Tahun 1945. Pelaksanaan pemilu memiliki banyak dinamika, antara lain biaya perahu politik yang mahal, dana kampanye yang mahal untuk politik pencitraan, ongkos konsultasi dan survei pemenangan yang mahal serta politik uang. Keterbukaan keuangan partai politik sangat penting di dalam pelaksanaan pemilu, karena banyak aliran hasil korupsi yang dipakai dalam pemilu. Akibatnya masyarakat tidak percaya kepada partai politik, atau sebagian masyarakat Indonesia mulai tidak lagi simpatik pada partai poltik. Gagasan regulasi keterbukaan keuangan partai politik harus digagas dengan seksama di dalam rencana kodifikasi pemilu Indonesia. Kedepan Indonesia harus memiliki pengaturan dana kampanye atau dana politik yang transparan, akuntabel, serta memiliki sanksi yang tegas dan mengikat para pihak yang terlibat, sehingga masyarakat kembali percaya lagi kepada partai politik, dan yakin partai politik tempat menyalurkan aspirasi mereka dalam pemberian hak dalam pemilu.

Kata Kunci: Keuangan; Partai Politik; Korupsi

\footnotetext{
* Naskah diterima: 26 Juli 2016, direvisi: 23 Agustus 2016, disetujui untuk terbit: 30 September 2016.
} 


\section{Laurensius Arliman S}

\section{Pendahuluan}

Para pendiri negara Indonesia telah mengadopsi nilai-nilai demokrasi yang berlaku dan mendarah daging dalam kehidupan masyarakat Indonesia sebagai sistem pemerintahan dengan merumuskannya dalan Undang-Undang Dasar 1945 (UUD 1945) Pasal 1 ayat (2) menyatakan bahwa "kedaulatan berada di tangan rakyat dan dilaksanakan menurut Undang-Undang Dasar." Hal ini menunjukkan bahwa bangsa Indonesia telah memiliki dan menerapkan nilainilai demokrasi pada tataran kehidupan di masa lalu sebagai nilai-nilai asli bangsa Indonesia. Nilai-nilai demokrasi tersebut telah berkembang dalam budaya luhur bangsa Indonesia dan dipraktikkan dalam tata kehidupan bermasyarakat di masa lampau. Jadi penetapan demokrasi sebagai sistem pemerintahan di Indonesia sudah sangat efektif diterapkan di negara-negara lain di dunia, juga karena sistem demokrasi sudah mendarah daging sebagai nilai-nilai luhur bangsa Indonesia. Oleh sebab itu, penerapan demokrasi di Indonesia seharusnya sejalan dan didasarkan pada Pancasila dan UUD 1945. ${ }^{1}$ Sebagai sarana pelaksanaan kedaulatan rakyat, pemilihan umum pasca perubahan UUD 1945 mengalami perkembangan yang amat pesat. Hal itu ditandai dengan tinggilnya tingkat kebutuhan akan aturan pemilu dan banyaknya jenis pemilu yang mesti dilaksanakan dalam satu periode pemerintahan. Hanya saja, perkembangan tersebut juga membawa dampak terhadap munculnya kompleksitas. ${ }^{2}$

Pemilihan umum (general election) dilaksanakan secara berkala dan periodik teratur dan berkesinambungan. Dengan adanya sistem demokrasi yang teratur itulah kesejahteraan dan keadilan dapat dijamin perwujudannya secara tahap demi tahap dengan sebaik-baiknya. Kegiatan ini pula merupakan salah satu sarana penyaluran hak asasi warga negara yang sangat prinsipal. Oleh karena itu dalam rangka pelaksanaan hak asasi warga negara adalah keharusan bagi pemerintah untuk menjamin terlaksananya penyelenggaraan pemilihan umum sesuai dengan jadwal ketatanegaraan yang telah ditentukan.

Dalam sistem demokrasi modern bagaimanapun legalitas dan legitimasi pemerintahan di satu pihak harus terbentuk berdasarkan ketentuan

\footnotetext{
1 Sutarman, Penyidikan Tindak Pidana Pemilukada dan Antisipasi Gangguan Kamtibmas dalam Mewujudkan Pemilukada yang Aman dan Demokratis, dalam: Konpress, Demokrasi Lokal Evaluasi Pemilukada Di Indonesia, (Jakarta, Konstitusi Pers, 2012), h. 127.

2 Saldi Isra, Gagasan Kodifikasi Undang-Undang Pemilu, disampaikan Dalam Konsultasi Publik Kodifikasi Undang-Undang Pemilu, Pembaharuan Desain Penegakan Hukum Pemilu, Kerjasama Sekretariat Bersama Kodifikasai Undang-Undang Pemilu dengan Pusat Studi Konstitusi (PUSaKO) Fakultas Hukum Universitas Andalas, Padang 10 Juni 2016, h. 1.
} 
hukum dan konstitusi, sehingga dapat dikatakan menjadi legalitas. Di pihak lain pemerintah juga harus legitimate, dalam arti bahwa di samping legal, ia juga harus dipercaya. Artinya setiap pemerintahan demokratis yang mengaku berasal dari rakyat memang harus sesuai dengan hasil pemilihan umum sebagai ciri yang penting atau pilar yang pokok dalam sistem demokrasi modern. ${ }^{3}$ Di level local government, pemilu diaktualisasikan ke dalam pranata pemilukada. ${ }^{4}$ Di sini, ada ruang deliberasi bagi masyarakat untuk menentukan arah pemerintahan di daerah. Begitu juga, ada deliberasi partisipasi warga dalam menentukan kepemimpinan di daerah. Melalui pemilukada, kebijakankebijakan yang dibuat oleh kepala daerah terpilih akan dirumuskan berdasarkan taste masyarakat, termasuk implementasinya. Kebijakan-kebijakan publik yang menguntungkan masyarakat merupakan ujung dari perbaikan demokrasi lewat pemilukada. ${ }^{5}$

Masih segar diingatan bahwa perhelatan akbar Pemilu Kepala Daerah saat ini merupakan momentum yang sangat ditunggu-tunggu bagi para calon kepala daerah. Pada pemilihan kepala daerah tanggal 9 Desember tahun 2015, untuk kali pertama dilaksanakan dengan serentak di seluruh daerah Indonesia yang terdiri dari 825 pasangan calon. Calon-calon pemimpin kepala daerah dan wakil kepala daerah ini berasal dari bakal calon gabungan partai politik, partai politik tunggal dengan syarat tertentu, ataupun yang berasal dari perorangan atau independen.

Wajah-wajah calon kepala daerah ataupun wakil kepala daerah yang tampil pada pilkada serentak ini beragam, ada wajah muka lama atau incumbent dan juga wajah baru yang nantinya diharapkan mendapatkan simpatik dari rakyat daerahnya. Pasangan calon wakil kepala daerah dan wakil kepala daerah ini, ada yang berjenis kelamin sama yaitu laki-laki dan laki-laki, perempuan dan perempuan, ataupun laki-laki dan perempuan. Selain itu ada pula calon kepala daerahnya perempuan dan wakil kepala daerahnya laki-laki ataupun sebaliknya laki-laki sebagai calon kepala daerah dan perempuan sebagai calon wakil kepala daerah.

${ }^{3}$ Dedi Lulyadi, Perbandingan Tindak Pidana Pemilu Legislatif dalam Perspektif Hukum di Indonesia, (Bandung: PT. Refika Aditama, 2013), h. 54-55.

${ }_{4}^{4}$ Moh. Mahfud MD, Evaluasi Pemilukada dalam Perspektif Demokrasi dan Hukum, dalam: Konpress, Demokrasi Lokal Evaluasi Pemilukada di Indonesia, (Jakarta, Konstitusi Pers, 2012), h. 6.

${ }^{5}$ Kacung Marijan, Resiko Politik, Biaya Ekonomi, Akuntabilitas Politik dan Demokrasi Lokal, makalah yang disampaikan pada In House Discussion Komunikasi Dialog Partai Politik, yang diselenggarakan oleh Komunitas Indonesia untuk Demokrasi (KID) di Jakarta, 16 November 2007, h. 9 . 


\section{Laurensius Arliman S}

Terlepas dari pilkada, hal yang sama juga terlihat di dalam pemilihan umum Presiden dan Wakil Presiden, pemilihan umum Dewan Perwakilan Rakyat Republik Indonesia (DPR-RI), pemilihan umum Dewan Perwakilan Daerah Republik Indonesia (DPD-RI), pemilihan umum Dewan Perwakilah Rakyat Daerah Provinsi (DPRD Provinsi), pemilihan umum Dewan Perwakilan Rakyat Kota/Kabupaten (DPR Kota/Kabupaten) calon-calon yang muncul pun beraneka ragam, dan memiliki semboyan dan slogan yang mudah untuk diingat.

Hal ini dilaksanakan, dengan harapan agar para pemilih memilih mereka, karena semboyan dan slogan yang mudah diingat tersebut bisa langsung dipilih oleh para pemilih di dalam bilik pilih. Dikaji lebih jauh mengenai pemilu Presiden dan Wakil Presiden, pemilu legislatif, dan pilkada memiliki dinamika tersendiri, dari pemilih yang bisa memilih lebih dari satu, penggelembungan surat suara, melibatkan anak dalam kampanye, surat suara yang fiktif, black campaign, serangan fajar, dan hal lain sebagainya yang sudah dilarang di dalam aturan perundang-undangan tentang pemilu Presiden dan Wakil Presiden, pemilu legislatif, dan pilkada sampai dengan adanya dugaan praktik pencucian uang dari hasil korupsi untuk membiayai kampanye para calon didalam pelaksanaan pemilihan umum.

Pendanaan partai politik yang mengusung para calon haruslah benarbenar jelas. Secara praksis, keberadaan partai secara faktual hanya bergaung seolah menjadikan rakyat sebagai tema sentral jelang kampanye dan atau saat kampanye dilakukan melalui kegiatan sosial, event olah raga, demonstrasi ataupun tampilan lips service lainnya yang menjadikan rakyat sebagai komoditas. Namun ketika telah terpilih menjadi wakil rakyat dan bahkan berada pada lingkungan elite kekuasaan, kadang mereka menestapakan harapan rakyat yang terbuai oleh setumpuk janji di tengah hingar bingar hajatan demokrasi lima tahunan tersebut. Bahkan dalam beberapa kasus hukum misalnya antar elite terkesan saling melindungi, menutupi kesalahan, dan ironisnya melakukan korupsi berjamaah. ${ }^{6}$

Di tengah kemeriahan pelaksanaan pemilu yang menghabiskan dan milyaran rupiah ini, ternyata masih menyisakan berbagai permasalahan yang dapat mengganggu pelaksanaan pemilu tersebut. ${ }^{7}$ Seharusnya regulasi pendanaan politik harus dapat mengatur dengan jelas sistem pengawasan,

\footnotetext{
${ }^{6}$ Armansyah Nasution, “Quo Vadis Partai Politik?," dalam Jurnal Ultimatum, Volume 1 Nomor 1, Agustus 2008, Jakarta: STIH Iblam, h. 36.

7 Bambang Eka Cahya Widodo, "Pemilu: Tanggung Jawab Kita Bersama," dalam Jurnal Ultimatum, Volume 1 Nomor 1, Agustus 2008, Jakarta: STIH Iblam), h. 43.
} 
pengelolaan dan penegakan hukum jika terjadi pelanggaran terhadap norma hukum pendanaan kampanye, harus ada kejelasan, siapa yang menegakkan sistem aturan tersebut, bagaimana mekanisme pendanaan dilakukan serta pengawasan terhadap para penyumbang dalam membangun governance partai politik yang baik. ${ }^{8}$ Dalam artikel ini penulis mencoba membahas beberapa poin antara lain: 1). Bagaimana dinamika keterbukaan keuangan partai politik dalam kampanye? 2). Apakah praktik pencucian uang hasil korupsi sebagai bentuk kemunduran kepercayaan masyarakat terhadap partai politik? 3). Memunculkan gagasan keterbukaan keuangan partai politik dalam pemilu dan pemilukada.

\section{Dinamika Keterbukaan Keuangan Partai Politik Dalam Pemilihan Umum}

Keberhasilan pengembangan demokrasi dalam pemilu (pemilu presiden dan wakil presiden, pemilu legislatif, pemilukada) secara langsung tergantung pada bekerjanya sistem-sistem seleksi tingkat partai politik, seleksi adminstratif oleh KPU, dan seleksi politis serta hati nurani rakyat. ${ }^{9}$ Menurut paham kedaulatan rakyat, rakyat memerintah dan mengatur diri mereka sendiri (demokrasi), hanya rakyat yang berhak mengatur dan menentukan pembatasan-pembatasan terhadap diri mereka sendiri, dalam arti bahwa pada tingkat terakhir rakyat memberikan ketentuan dalam masalah-masalah pokok mengenai kehidupannya, termasuk dalam menilai kebijaksanaan pemerintahan dan negara. Sebab, kebijaksanaan itulah yang menentukan kehidupan rakyat. ${ }^{10}$

Pelaksanaan kedaulatan rakyat tidak dapat dilepaskan dari pemilu karena pemilu merupakan konsekuensi logis dianutnya prinsip kedaulatan rakyat (demokrasi) dalam kehidupan berbangsa dan berbegara. Prinsip dasar kehidupan kenegaraan yang demokratis adalah setiap warga negara berhak ikut aktif dalam proses politik. ${ }^{11}$ Untuk itu, kualitas partai politik, baik keorganisasiannya maupun kiprahnya dalam kehidupan politik, sangat menentukan terciptanya wakil-wakil rakyat yang bermutu dan

${ }^{8}$ W. Riawan Tjandra dan Mery Christian Putri, Pendanaan Kampanye: Antara Demokrasi dan Kriminalisasi, dalam: Khairul Fahmi, Charles Simabura dan Feri Amsari, Pemilihan Umum Serentak, (Jakarta: PT. RajaGrafindo Persada, 2015), h. 622.

9 Suharizal, "Reformulasi Pemilukada, Beberapa Gagasan Menuju Penguatan Pemilukada," dalam Jurnal Konstitusi, Volume IV Nomor 1, Juni 2011, (Jakarta: Mahkamah Konstitusi), h. 73.

10 Refly Harun, Pemilu Konstitusional Desain Penyelesaian Sengketa Pemilu Kini dan Ke Depan, (Jakarta: PT. RajaGrafindo Persada, 2016), h. 33.

11 Dahlan Talib, Implementasi Sistem Ketatanegaraan Menurut UUD 1945, (Yogyakarta: Liberty, 1993), h. 94. 


\section{Laurensius Arliman S}

bertanggungjawab. Demikian pula pemilu merupakan proses untuk melakukan seleksi yang "menyeberangkan" tokoh-tokoh dari sektor kehidupan politik masyarakat ke sektor pemerintahan yang resmi sifatnya. ${ }^{12}$

Dalam kurun waktu pelaksanaan Pemilu, khususnya pasca keruntuhan Soeharto, partai tumbuh dengan pesat dan terus mencari bentuk walaupun platform yang ditawarkan tidak asing lagi di telinga kita, seperti memutar lagu lama atau berlomba menjual kecap nomor wahid yang menyingkirkan substansi detail dari konkritisasi kinerja secara spesifik, tidak fokus pada apa yang akan mereka kerjakan melalui mesin politik guna kebaikan rakyat sebagaimana amanat konstitusi. Tegasnya secara periodik isu who gets what, when, where, how, why, and what impact sebatas komoditas headline surat kabar, namun titik singgung krusialnya tidak menyentuh akar persoalan, sehingga kualitas partai berikut visi misi yang diusung semakin diragukan mampu merespon aspirasi rakyat, terlebih nuansa kepentingan politik menjadi berhala mengalahkan fakta dan kebutuhan sosial itu sendiri yang pada akhirnya mempengaruhi sistem demokrasi di negara ini. ${ }^{13}$ Berbagai persoalan yang terjadi sampai saat ini memang belum sampai pada titik yang benar-benar mengancam pelaksanaan pemilu.

Fakta menunjukkan bahwa demokrasi di tingkat lokal dibajak oleh kepentingan modal dan kekuasaan. Praktik politik uang dan politisasi birokrasi mendominasi pelaksanaan pemilu. Operasi pembajakan demokrasi melibatkan dana puluhan miliar rupiah. Hitung saja berdasarkan item pengeluaran dan gegap gempitanya kontestasi kandidat. Untuk biaya pencalonan (ongkos perahu politik), tim pemenangan, survey, atribut kampanye, sumbangan ke kantong pemilih, membeli suara, kampanye di media cetak dan elektronik, hingga menyiapkan saksi pada saat pemungutan suara. Angka yang fantastis dan tak sebanding dengan pendapatan resmi yang bakal diterima. Gubernur misalnya, hanya memperoleh gaji Rp. 8,6 juta/bulan atau total Rp. 165 juta selama lima tahun menjabat. Lantas dari mana "aktoraktor" demokrasi ini akan mengembalikan modal yang telah mereka keluarkan? Inilah awal bangkrutnya negeri ini akibat ulah "aktor" demokrasi aji mumpung tersebut. Korupsi dan koalisi (bermufakat) jahat menjadi cara

12 Rusadi Kantaprawira, Anjakan Analisis Politik dan Ketatanegaraan Atas Dasar Daur Parlemen, dalam Bagir Manan (Editor), Kedaulatan Rakyat, Hak Asasi Manusia dan Negara Hukum, (Jakarta, Gaya Media Pratama, 1996), h. 255.

${ }^{13}$ Armansyah Nasution, "Quo Vadis Partai Politik?," h. 36.

230 - Jurnal Cita Hukum. Vol. 4 No. 2 Desember 2016. P-ISSN: 2356-1440. E-ISSN: 2502-230X 
untuk mengeruk dan menguras habis tanpa sisa pundi-pundi kesejahteraan rakyat. ${ }^{14}$

Dana kampanye untuk politik pencitraan yang mahal. Pemilukada langsung memang memberikan tantangan bagi demokrasi. Sistem demokrasi liberal, menuntut kandidat memiliki angka popularitas tinggi untuk memperoleh suara mayoritas. Tujuannya agar kepala daerah terpilih lebih dekat dengan pemilih. Namun persoalan muncul ketika partai politik dan kandidat tidak bekerja secara maksimal meraih suara. Cara-cara instan justru menjadi pilihan utama, pencitraan melalui media cetak, elektronik dan ruangruang publik lainnya dengan hanya menampilkan gambar wajah semata. Pemilih diposisikan semata-mata sebagai komoditi politik disuguhkan iklan politik tanpa dapat mengenal lebih jauh kandidat. Konsekuensinya, kekuatan modal menjadi pendukung utama. ${ }^{15}$

Ongkos konsultasi dan survei pemenangan yang mahal. Bisnis konsultan dan survei pemenangan memang manjanjikan. Terbukti semakin marak munculnya lembaga-lembaga survei yang kemudian digunakan kandidat untuk mengukur elektabilitas pencalonan. Tentunya tidak sedikit anggaran yang dikeluarkan untuk itu. ${ }^{16}$ Serta politik uang yang semakin merajalela, ${ }^{17}$ demi melancarkan monopoli suara, maka para calon berani untuk melakukan politik uang secara besar-besaran, agar dapat duduk di "kursi panas" yang diidamkan.

Menurut Edward Aspinal, politik uang hanya ada di Indonesia, sedangkan menurut Daniel Bumke karakteristik politik uang antara lain: 1) Vote Buying, merupakan pertukaran barang, jasa, atau uang dengan suara dalam pemilihan umum; 2) Vote Broker, orang yang mewakili kandidat/partai untuk membeli suara ; 3) Korupsi Politik, segala bentuk suap kepada politisi dalam rangka mendapatkan kebijakan yang menguntungkan atau keuntungan lainnya. ${ }^{18}$

14 Topo Santoso dan Tim Perludem, Pemilukada Pengalaman dan Penataan Kembali, dalam: Konpress, Demokrasi Lokal Evaluasi Pemilukada di Indonesia, (Jakarta, Konstitusi Pers, 2012), h. 192193.

h. 38 .

15 Topo Santoso dan Tim Perludem, Pemilukada Pengalaman dan Penataan Kembali, h. 194.

16 Topo Santoso dan Tim Perludem, Pemilukada Pengalaman dan Penataan Kembali, h. 195.

17 Nur Syamsi Nurlan, Kiat-Kiat Memenangkan Pilkada, (Padang: Khatulistiwa Press, 2005),

18 Donal Fariz, Pengawasan Dana Politik, disampaikan Dalam Konsultasi Publik Kodifikasi Undang-Undang Pemilu, Pembaharuan Desain Penegakan Hukum Pemilu, Kerjasama Sekretariat Bersama Kodifikasai Undang-Undang Pemilu dengan Pusat Studi Konstitusi (PUSaKO) Fakultas Hukum Universitas Andalas, Padang 10 Juni 2016, h. 2. 


\section{Laurensius Arliman S}

Senada dengan itu, Indonesia Corruption Watch (ICW) menyatakan, bahwa problem integritas pemilu ada tiga penyebab, yaitu:19 1). maraknya praktik politik transaksional negatif (politik uang); 2). dana kampanye haram sebagai modal politik; dan 3). penggunaan fasilitas negara dan daerah sebagai instrument pemenangan.

\section{Praktik Pencucian Uang Hasil Korupsi Sebagai Bentuk Kemunduran Kepercayaan Masyarakat Terhadap Partai Politik}

Pemilu merupakan salah satu tahap krusial dalam perwujudan demokrasi (kedaulatan rakyat) rakyat secara lansung menentukan representasi politik, akuntabilitas politik para wakil rakyat dan pemerintah, menentukan pasangan presiden dan wakil presiden baru, atau menghukum presiden yang sedang menjabat agar tidak dipilih kembali, menentukan representasi daerah (teritorial), menentukan eksekutif lokal. Terdapat banyak competitor dalam pemilu: ribuan calon angota DPD, belasan parpol dengan ribuan calon anggota DPR/DPRD, beberapa pasangan calon presiden-wakil presiden atau pasangan kepala daerah-wakil kepala daerah. Persaingan ketat, pelanggaran, kecurangan dan perselisihan dapat terjadi. Diperlukan pihak ketiga (imparsial) untuk menilai dan mengadili kompetisi politik. ${ }^{20}$

Dalam studi kejahatan, tindak pidana pemilu juga dapat dimasukkan dalam tindak pidana korupsi. ${ }^{21}$ Dua dari sembilan tipe korupsi berkaitan langsung dengan pemilu adalah election fraud dan corrupt campaign practice. Election fraud adalah korupsi yang berkaitan langsung dengan kecurangan pemilihan umum. Termasuk dalam election fraud ini adalah pendaftaran pemilih yang sengaja dilakukan secara tidak akurat, kecurangan dalam penghitungan suara dan membayar sejumlah uang tertentu atau memberi barang atau janji agar memilih calon tertentu dalam pemilu. Sedangkan corrupt campaign practice adalah praktik kampanye dengan menggunakan fasilitas negara maupun uang negara oleh calon yang sedang memegang kekuasaan negara. ${ }^{22}$

19 Donal Fariz, Pengawasan Dana Politik, disampaikan Dalam Konsultasi Publik Kodifikasi Undang-Undang Pemilu, h. 2.

${ }^{20}$ Mohammad Fajrul Faalakh, "Peradilan Hail Pemilu," dalam Jurnal Konstitusi, Volume IV Nomor 1, Juni 2011, (Jakarta: Mahkamah Konstitusi), h. 32.

${ }^{21}$ Eddy O.S Hiariej, Pemilukada Kini dan Masa Datang Persepektif Hukum Pidana, dalam Konpress, Demokrasi Lokal Evaluasi Pemilukada Di Indonesia, (Jakarta, Konstitusi Pers, 2012), h. 179.

22 Piers Beims dan James Messerschmidt, Criminilogy, Second Edition (Harcourt Brage College Publishers, 1995), h. 295-297.

232 - Jurnal Cita Hukum. Vol. 4 No. 2 Desember 2016. P-ISSN: 2356-1440. E-ISSN: 2502-230X 
Proses pendanaan partai politik pada pemilu sebagai sebuah pemisalan. Meski ada kewajiban menyerahkan rekening khusus dana kampanye dengan batasan waktu tertentu, tetapi tetap saja hanya prosedural yang tidak substansif. Menarik, ada partai besar dengan jumlah dana sangat kecil, sedangkan ada partai baru (kecil) dengan dana terbesar. Hal lainnya, ada partai yang telah "jorjoran" belanja kampanye media, tetapi hanya melaporkan dana kampanye yang sangat kecil jumlahnya dibandingkan dengan taksiran yang telah ia keluarkan. Hal yang seakan menggambarkan tidak adanya kerelaan dan kewajiban untuk melengkapi semua hal tersebut. ${ }^{23}$

Rekening khusus dana kampanye didefinisikan sebagai rekening khusus yang menampung dana kampanye pemilu yang dipisahkan dari rekening keuangan partai politik atau rekening keuangan pribadi calon Anggota DPD. Rekening khusus ini diperuntukkan guna menempatkan atau menampung dana kampanye pemilu masing-masing parpol peserta pemilu. Laporan awal dana kampanye dan rekening khusus dana kampanye menyajikan informasi mengenai nama bank, nomor rekening, nama pemegang rekening dan saldo pembuka rekening. ${ }^{24}$ Bahkan di dalam memenuhi kebutuhannya yang besar itu para calon berani melakukan praktik pencucian uang hasil korupsi untuk membiayai rekening kampanye pemilunya.

Suatu fenomena sosial yang dinamakan korupsi merupakan realitas perilaku manusia dalam interaksi sosial yang dianggap menyimpang, serta membahayakan masyarakat dan negara. Oleh karena itu, perilaku tersebut dalam segala bentuk dicela oleh masyarakat, bahkan termasuk oleh para koruptor itu sendiri sesuai dengan ungkapan "koruptor teriak koruptor." Pencelaan masyarakat terhadap korupsi menurut konsepsi yuridis dimanifestasikan dalam rumusan hukum sebagai bentuk tindak pidana. Di dalam politik hukum pidana Indonesia, korupsi itu bahkan dianggap sebagai bentuk tindak pidana yang perlu didekati secara khusus, dan diancam dengan pidana yang cukup berat. Dalam sejarah kehidupan hukum pidana Indonesia, istilah korupsi pertama kali digunakan di dalam Peraturan Penguasa Militer Nomor Prt/PM-06/1957, sehingga korupsi menjadi suatu istilah hukum. Penggunaan istilah korupsi dalam peraturan tersebut terdapat bagian konsiderannya, yang antara lain menyebutkan, bahwa perbuatan-perbuatan

${ }^{23}$ Zainal Arifin Mochtar, Melawan Korupsi (Membaca Saldi Isra di Altar Demokrasi), dalam: Saldi Isra, Membangun Demokrasi Membongkar Korupsi, (Jakarta: PT. RajaGrafindo Persada, 2010), h. XXX.

24 Khairul Fahmi, Pembatalan Partai Politik sebagai Peserta Pemliu (Studi Kasus Pembatalan Partai Politik Peserta Pemilu 2009 di Kabupaten Kepulauan Mentawai, (Jurnal Konstitusi, Volume IV Nomor 1, Juni 2011, Jakarta: Mahkamah Konstitusi), h. 95. 


\section{Laurensius Arliman S}

yang merugikan keuangan dan perekonomian negara yang oleh khalayak ramai dinamakan korupsi. ${ }^{25}$

Sekarang di Indonesia jika orang berbicara mengenai korupsi, pasti yang dipikirkan hanya perbuatan jahat menyangkut keuangan negara dan suap. Pendekatan yang dapat dilakukan terhadap masalah korupsi bermacam ragamnya, dan artinya tetap sesuai walaupun kita mendekati masalah itu, dari berbagai aspek. Pendekatan sosiologis misalnya, seperti halnya yang dilakukan oleh Syed Hussein Alatas dalam bukunya The Sociology of Corruptioon, akan lain artinya kalau kita melakukan pendekatan normatif; begitu pula dengan politik ataupun ekonomi. Misalnya Alatas memasukan "nepotisme" dalam kelompok korupsi, dalam klasifikasinya (memasang keluarga atau teman pada posisi pemerintahan tanpa memenuhi persyaratan untuk itu), yang tentunya hal seperti itu sukar dicari normanya dalam hukum pidana. ${ }^{26}$

Berkembang di media masa, bahwa sudah meluasnya virus korupsi ke daerah. Di era Orde Baru, korupsi tersentralisasi di Jakarta, terpusat pada eksekutif, seiring dengan desentralisasi dan otonomi, maka terdensentralisasi pula korupsi. Korupsi bukan hanya terjadi di pusat, melainkan juga di daerah, bukan hanya pada eksekutif, melainkan legislatif. ${ }^{27}$ Akibat dari praktik pencucian uang hasil korupsi menyebabkan kemunduran kepercayaan masyarakat terhadap partai politik dan pemilihan umum itu sendiri. Karena masyarakat tidak akan memberikan hak pilihnya di dalam pelaksanaan pemilihan umum atau lebih dikenal dengan kata-kata golongan putih (golput). Kata-kata golput sudah tidak asing lagi didengar ketika pemilu tiba. Istilah golput muncul pertama kali dari mahasiswa dan pemuda pasca tumbangya orde lama. Pilihan mahasiswa dan pemuda ketika itu berada posisi golput, yang merupakan sebagai bentuk tindakan perlawanan terhadap penguasa yang selalu bersifat represif.

Pemilu era reformasi ini sangat berbeda dengan pemilu di era tahun 70an. Di era reformasi ini masyarakat memiliki kebebasan untuk memiliki caloncalon pemimpin yang terbaik. Sebagai rakyat yang cerdas, sudah seharusnya kita mengambil peran dalam mendukung suksesnya pemilu dengan berpartisipasi. Tidak golput merupakan bentuk kesukarelaan rakyat yang telah

25 Elwi Danil, Korupsi: Tindak Pidana, dan Pemberantasannya (Jakarta: PT. RajaGrafindo Persada, 2011), h. 1-5.

${ }^{26}$ Andi Hamzah, Pemberantasan Korupsi Melalui Hukum Pidana Nasional dan Internasional, Cetakan Kelima, (Jakarta: PT. RajaGrafindo Persada, 2012), h. 5-6.

27 Budiman Tanuredjo, Pilkada Lansung: Menutar Jarum Jam Sejarah Mungkinkah?, dalam Konpress, Demokrasi Lokal Evaluasi Pemilukada Di Indonesia, (Jakarta, Konstitusi Pers, 2012), hlm. 246. 
diberi wewenang untuk memilih siapa jagoan mereka yang akan menduduki jabatan selanjutnya. Kesukarelaan masyarakat akan menjadi momentum luar biasa sebab pilihan masyarakat di balik suara adalah penentu perubahan.

\section{Gagasan Keterbukaan Keuangan Partai Politik Dalam Pemilu dan Pemilukada}

Pembenahan sistem pemilihan umum dimaksudkan untuk mencapai tujuan penyelenggaraan pemilu yang selalu menjadi panduan utama. Dengan berpatokan pada pencapaian tujuan pemilu dan dengan menggunakan bingkai prinsip-prinsip kedaulatan rakyat, maka menjadi keharusan untuk memilih satu sistem pemilu tertentu yang memadai untuk itu. Untuk melengkapi pencapaian tujuan pemilu dan melaksanakan prinsip kedaulatan rakyat, maka berbagai kelemahan yang tidak dapat ditutupi melalui pembenahan sistem pemilu harus dicarikan jalan lain. ${ }^{28}$ Salah satunya yaitu dengan keterbukaan pendanaan keuangan partai politik di dalam melaksanakan pemilu, sehingga masyarakat percaya kepada partai politik yang dipilihnya, merupakan partai politik yang bebas dari budaya korupsi, sehingga melahirkan kader antikorupsi.

Pemilihan umum merupakan sarana untuk memfasilitasi proses perebutan mandat rakyat untuk memperoleh kekuasaan. Dalam pemilu, rakyat sebagai pemegang kedaulatan negara memilih pemimpin yang akan menentukan nasibnya untuk lima tahun ke depan. ${ }^{29}$ Menurut Jimly Asshiddiqie, tujuan penyelenggaraan pemilihan umum itu ada empat, yaitu: 1). untuk memungkinkan terjadinya peralihan kepemimpinan pemerintahan secara tertib dan damai; 2). untuk memungkinkan terjadinya pergantian pejabat yang akan mewakili kepentingan rakyat di lembaga perwakilan; 3). untuk melaksanakan prinsip kedaulatan rakyat di lembaga perwakilan; 4). dan untuk melaksanakan prinsip hak-hak asasi warga negara. ${ }^{30}$

Pengaturan keterbukaan keuangan partai politik haruslah menjadi pokok penting yang harus dilaksanakan dan digagas untuk kedepannya, karena aturan yang ada sepertinya tidak terlalu mengawal dengan ketat mengenai keterbukaan keuangan partai politik, di mana masih adanya

28 Khairul Fahmi, Pemilihan Umum \& Kedaulatan Rakyat (Jakarta: PT. RajaGrafindo Persada, 2012), h. 275-276.

${ }^{29}$ M. Zaid Wahyudi, Menjaga Pemilu Tetap Luber, Jurdil, Harian Kompas, 10 Maret 2007, h. 7.

30 Jimly Asshiddiqie, Pengantar Ilmu Hukum Tata Negara, Jilid II, (Jakarta: Sekretariat Jenderal dan Kepaniteraan Mahkamah Konstitusi Repuplik Indonesia, 2006), h. 175. 


\section{Laurensius Arliman S}

dinamika-dinamika dalam pemilihan umum, baik dalam proses menjadi bakal calon, kampanye dalam pemilihan umum, serta dalam pelaksanaan hak pilih dan penghitungan surat suara itu sendiri.

Regulasi pemilihan umum era reformasi sejak tahun 2000 sampai dengan tahun 2015 berdasarkan pemilu legislatif, pemilu presiden, dan pilkada terdapat 14 (empat belas) undang-undang, yaitu; ${ }^{31} 1$ ). Undang-Undang Nomor 12 tahun 2004; 2). Undang-Undang Nomor 22 tahun 2004; 3). Undang-Undang Nomor 10 tahun 2006; 4). Undang-Undang Nomor 10 tahun 2008; 5). UndangUndang Nomor 08 tahun 2012; 6). Undang-Undang Nomor 23 tahun 2004; 7). Undang-Undang Nomor 43 tahun 2004; 8). Undang-Undang Nomor 32 tahun 2004; 9). Undang-Undang Nomor 08 tahun 2005; 10). Undang-Undang Nomor 12 tahun 2008; 11). Undang-Undang Nomor 01 tahun 2015; 12). UndangUndang Nomor 08 tahun 2015; 13). Undang-Undang Nomor 22 tahun 2007; dan 14). Undang-Undang Nomor 15 tahun 2011.

Meskipun sudah ada regulasi yang selalu berubah-berubah sesuai dengan perkembangan politik dan peraturan perundang-undangan yang ada, pengaturan terhadap keterbukaan keuangan partai politik memang selalu dimasukkan dalam sebuah regulasi tersebut, namun dalam kenyataannya aturan keterbukaan keuangan partai politik tersebut tidak efektif dan budaya korupsi tetap saja terjadi, hal ini bisa dilihat dari berita-berita yang ditayangkan oleh media masa.

Adanya gagasan untuk membuat kodifikasi undang-undang pemilu merupakan suatu terobosan yang sangat baik, demi menjamin keberlangsungan pemilu yang luber dan jurdil (hal ini merupakan asas dalam pemilihan umum, yaitu: langsung, ${ }^{32}$ umum, ${ }^{33}$ bebas $^{34}{ }^{34}$ ahasia, ${ }^{35}$ jujur, ${ }^{36}$ adil ${ }^{37}$ )

${ }^{31}$ Sri Budi Eko Wardani, Naskah Akademik Rancangan Undang-Undang Pemilu, disampaikan Dalam Konsultasi Publik Kodifikasi Undang-Undang Pemilu, Pembaharuan Desain Penegakan Hukum Pemilu, Kerjasama Sekretariat Bersama Kodifikasai Undang-Undang Pemilu dengan Pusat Studi Konstitusi (PUSaKO) Fakultas Hukum Universitas Andalas, Padang 10 Juni 2016, h. 2.

32 Rakyat sebagai pemilih mempunyai hak untuk memberikan suaranya secara lansung seseuai kehendak hati nuraninya, tanpa ada perantara.

${ }^{33}$ Semua warga negara yang memenuhi persyaratan berhak mengikuti pemilu.

${ }^{34}$ Setiap warga negara berhak memilih bebas menentukan pilihannya tanpa tekanan dan paksaan dari siapapun.

${ }^{35}$ Dalam memberikan suaranya, pemilih dijamin bahwa pilihannya tidak akan diketahui oleh pihak mana pun dan dengan jalan apa pun.

${ }^{36}$ Setiap penyelenggaraan, pemilih, peserta, aparat pemerintah, serta semua pihak yang terkait harus bersikap dan bertindak jujur sesuai dengan peraturan perundang-undangan.

${ }^{37}$ Setiap pemilih dan peserta mendapat perlakuan yang sama serta bebas dari kecurangan pihak mana pun.

236 - Jurnal Cita Hukum. Vol. 4 No. 2 Desember 2016. P-ISSN: 2356-1440. E-ISSN: 2502-230X 
serta membuat masyarakat percaya akan partai politik kedepan. Karena saat ini masyarakat sepertinya kehilangan kepercayaan kepada partai politik, hal yang paling jelas dan nyata adalah banyak calon independen yang berhasil dalam pelaksanaan pilkada, dan bahkan yang sangat hangat sampai dengan tahun 2016 ini, adalah keinginan dari Gubenur DKI, Jakarta yaitu "Ahok" yang ingin maju kembali lagi dengan jalur independen, di mana masyarakat beramairamai memberikan KTP-nya untuk memberikan dukungan pada "ahok", selain itu para pendukung ahok dalam mengumpulkan KTP melaksanakan keterbukaan keuangan dalam penggalangan dukungan pada "Ahok". Apakah hal ini bisa ditiru oleh partai politik?

Politik bisa diartikan sebagai cara meraih kekuasaan negara atau pemerintah secara sah. Oleh karena praktik politik dan perangai para politikus belakangan ini, masyarakat cenderung beranggapan bahwa politik kotor itu sehingga masyarakat merasa segan untuk berdekatan dengan masalah politik. Sebagian masyarakat merasa segan untuk berdekatan dengan masalah politik. Sebagian masyarakat malahan menganggap urusan politik sebagai sesuatu yang tabu. Mereka alergi dengan masalah-masalah politik, padahal kehidupan sehari-hari masyarakat sebagian besar ditentukan oleh kebijakan politik. Kesalahan kebijakan atau keputusan politik akan berakibat pada kesengsaraan masyarakat, bahkan juga seluruh bangsa. Itulah sebabnya kaitan antara politik akan berakibat pada kesengsaraan masyarakat, bahkan juga seluruh bangsa.

Itulah sebabnya kaitan antara politik dengan etika menjadi sangat kuat. Politik yang baik adalah politik yang beretika. Politikus yang baik adalah politikus yang bermoral. Secara normatif, politikus akan mendapat dukungan dari rakyat apabila ia mampu mendatangkan kesejahteraan bagi seluruh lapisan masyarakat; bukan hanya bagi kelompok atau diri pribadi si politikus. Norma seperti ini umum diketahui oleh masyarakat. Dalam praktik, sesuatu yang sangat normatif bisa mudah sekali berubah menjadi sesuatu yang bertentangan dengan norma-norma itu sendiri. Masih dapat diingat, bagaimana pemerintahan Orde Baru, Pendidikan Moral Pancasila, yang seharusnya menjadikan bangsa ini bermoral baik, justru telah memerosotkan sebagian besar moral politikus. Kemerosotan moral pemegang kekuasaan hampir selalu berdampak pada kemorosotan kesejahteraan. ${ }^{38}$

${ }^{38}$ Martinus D. Sitiumorang, Politik dan Moralitas, dalam: Editor Dua, Febiana R. Kainama, Kasdin Sihotang (Editor) Politik Katolik Politik Kebaikan Bersama, Sejarah dan Refleksi Keterlibatan Orang-Orang Katolik Dalam Politik Indonesia, (Jakarta: Penerbit Obor, 2008), h. IX-X. 


\section{Laurensius Arliman S}

Segala macam bentuk politik uang harus dapat dilawan karena beberapa alasan: 1). politik uang merusak sendi-sendi demokrasi bangsa ini; 2). politik uang adalah perbudakan modern; 3). politik uang merusak moral bangsa Indonesia; 4). politik uang akan menghasilkan pemimpin-pemimpin yang korup; dan 5). pelaku politik uang adalah penjahat. Dengan rancangan kodifikasi undang-udang pemilu, diharapkan ada aturan BAB khusus, atau benar-benar khusus dalam mengatur masalah keterbukaan keuangan partai politik ini. Agar kedepan ada pengaturan dana kampanye atau dana politik yang transparan, akuntabel, serta memiliki sanksi yang tegas dan mengikat para pihak yang terlibat.

\section{Penutup}

Pemilu adalah sarana pelaksanaan kedaulatan rakyat yang diselenggarakan secara luber dan jurdil di dalam Negara Kesatuan Republik Indonesia berdasarkan Pancasila dan Undang-Undang Dasar Negara Republik Indonesia Tahun 1945. Baik itu Pemilu Presiden dan Wakil Presiden, Pemilu Legislatif dan Pemilu Kepala Daerah. Pelaksanaan pemilu banyak mengalami dinamika, diantaranya biaya perahu politik yang mahal, dana kampanye yang mahal untuk politik pencitraan, ongkos konsultasi dan survei pemenangan yang mahal serta politik uang. Keterbukaan keuangan partai politik sangat penting sekali di dalam pelaksanaan pemilu, di mana sering terjadi hasil korupsi yang dilakukan bakal calon atau calon dalam pelaksanaan pemilu dipakai atau digunakan dalam kampanye, sampai dengan pelaksanaan pemilihan umum.

Akibatnya masyarakat tidak percaya lagi kepada partai politik, atau sebagai masyarakat Indonesia mulai tidak lagi simpatik pada partai politik, di mana mereka memilih menjadi golput dan juga memilih para calon yang berasal dari bukan calon partai politik atau independen. Gagasan regulasi keterbukaan keuangan partai politik harus digagas dengan seksama di dalam rencana kodifikasi pemilu. Agar ke depan ada pengaturan dana kampanye atau dana politik yang transparan, akuntabel, serta memiliki sanksi yang tegas dan mengikat para pihak yang terlibat, sehingga masyarakat kembali percaya lagi kepada partai politik, dan yakin bahwa partai politiklah tempat menyalurkan aspirasi mereka dalam pemberian hak dalam pemilu.

\section{Pustaka Acuan}

Asshiddiqie, Jimly, Pengantar Ilmu Hukum Tata Negara, Jilid II, Jakarta: Sekretariat Jenderal dan Kepaniteraan Mahkamah Konstitusi Repuplik Indonesia, 2006. 
Danil, Elwi, Korupsi: Tindak Pidana, dan Pemberantasannya, Jakarta: PT. RajaGrafindo Persada, 2011.

Faalakh, Mohammad Fajrul, Peradilan Hail Pemilu, Jurnal Konstitusi, Volume IV Nomor 1, Juni 2011, Jakarta: Mahkamah Konstitusi.

Fahmi, Khairul, Pembatalan Partai Politik sebagai Peserta Pemliu (Studi Kasus Pembatalan Partai Politik Peserta Pemilu 2009 di Kabupaten Kepulauan Mentawai, Jurnal Konstitusi, Volume IV Nomor 1, Juni 2011, Jakarta: Mahkamah Konstitusi.

Fahmi, Khairul, Pemilihan Umum \& Kedaulatan Rakyat, Jakarta: PT. RajaGrafindo Persada, 2012.

Fariz, Donal, Pengawasan Dana Politik, disampaikan Dalam Konsultasi Publik Kodifikasi Undang-Undang Pemilu, Pembaharuan Desain Penegakan Hukum Pemilu, Kerjasama Sekretariat Bersama Kodifikasai Undang-Undang Pemilu dengan Pusat Studi Konstitusi (PUSaKO) Fakultas Hukum Universitas Andalas, Padang 10 Juni 2016.

Hamzah, Andi, Pemberantasan Korupsi Melalui Hukum Pidana Nasional dan Internasional, Cetakan Kelima, Jakarta: PT. RajaGrafindo Persada, ,2012.

Harun, Refly, Pemilu Konstitusional Desain Penyelesaian Sengketa Pemilu Kini Dan Ke Depan, Jakarta: PT. RajaGrafindo Persada, 2016.

Hiariej, Eddy O.S, Pemilukada Kini dan Masa Datang Persepektif Hukum Pidana, dalam Konpress, Demokrasi Lokal Evaluasi Pemilukada Di Indonesia, Jakarta, Konstitusi Pers, 2012.

Isra, Saldi, Gagasan Kodifikasi Undang-Undang Pemilu, disampaikan Dalam Konsultasi Publik Kodifikasi Undang-Undang Pemilu, Pembaharuan Desain Penegakan Hukum Pemilu, Kerjasama Sekretariat Bersama Kodifikasai Undang-Undang Pemilu dengan Pusat Studi Konstitusi (PUSaKO) Fakultas Hukum Universitas Andalas, Padang 10 Juni 2016.

Kantaprawira, Rusadi, Anjakan Analisis Politik dan Ketatanegaraan Atas Dasar Daur Parlemen, dalam Bagir Manan (Editor), Kedaulatan Rakyat, Hak Asasi Manusia dan Negara Hukum, Jakarta, Gaya Media Pratama, 1996.

Lulyadi, Dedi, Perbandingan Tindak Pidana Pemilu Legislatif dalam Perspektif Hukum di Indonesia, Bandung: PT. Refika Aditama, 2013.

Mahfud MD, Moh, Evaluasi Pemilukada dalam Perspektif Demokrasi dan Hukum, dalam: Konpress, Demokrasi Lokal Evaluasi Pemilukada Di Indonesia, Jakarta, Konstitusi Pers, 2012.

Marijan, Kacung, Resiko Politik, Biaya Ekonomi, Akuntabilitas Politik dan Demokrasi Lokal, makalah yang disampaikan pada In House Discussion Komunikasi Dialog Partai Politik, yang diselenggarakan oleh Komunitas Indonesia untuk Demokrasi (KID) di Jakarta, 16 November 2007.

Messerschmidt, Piers Beims dan James, Criminilogy, Second Edition (Harcourt Brage College Publishers, 1995. 


\section{Laurensius Arliman S}

Mochtar, Zainal Arifin, Melawan Korupsi (Membaca Saldi Isra di Altar Demokrasi), dalam: Saldi Isra, Membangun Demokrasi Membongkar Korupsi, Jakarta: PT. RajaGrafindo Persada, 2010.

Nasution, Armansyah, Quo Vadis Partai Politik? Jurnal Ultimatum, Volume 1 Nomor 1, Agustus 2008, Jakarta: STIH Iblam.

Nurlan, Nur Syamsi Kiat-Kiat Memenangkan Pilkada, Padang: Kahtulistiwa Press.

Santoso, Topo dan Tim Perludem, Pemiluka Pengalaman dan Penataan Kembali, dalam: Konpress, Demokrasi Lokal Evaluasi Pemilukada Di Indonesia, (Jakarta, Konstitusi Pers, 2005, 2012.

Situmorang, Martinus D, Politik dan Moralitas, dalam: Editor Dua, Febiana R. Kainama, Kasdin Sihotang (Editor) Politik Katolik Politik Kebaikan Bersama, Sejarah dan Refleksi Keterlibatan Orang-Orang Katolik Dalam Politik Indonesia, Jakarta: Penerbit Obor, 2008.

Suharizal, Reformulasi Pemilukada, Beberapa Gagasan Menuju Penguatan Pemilukada, Jurnal Konstitusi, Volume IV Nomor 1, Juni 2011, Jakarta: Mahkamah Konstitusi.

Sutarman, Penyidikan Tindak Pidana Pemilukada dan Antisipasi Gangguan Kamtibmas dalam Mewujudkan Pemilukada yang Aman dan Demokratis, dalam: Konpress, Demokrasi Lokal Evaluasi Pemilukada Di Indonesia, Jakarta, Konstitusi Pers, 2012.

Talib, Dahlan, Implementasi Sistem Ketatanegaraan Menurut UUD 1945, Yogyakarta: Liberty, 1993.

Tanuredjo, Budiman, Pilkada Lansung: Menutar Jarum Jam Sejarah Mungkinkah?, dalam Konpress, Demokrasi Lokal Evaluasi Pemilukada Di Indonesia, Jakarta, Konstitusi Pers, 2012.

Tjandra, W. Riawan dan Mery Christian Putri, Pendanaan Kampanye: Antara Demokrasi Dan Kriminalisasi, dalam: Khairul Fahmi, Charles Simabura dan Feri Amsari, Pemilihan Umum Serentak, Jakarta: PT. RajaGrafindo Persada, 2015.

Wahyudi, M. Zaid, Menjaga Pemilu Tetap Luber, Jurdil, Harian Kompas, 10 Maret 2007.

Wardani, Sri Budi Eko, Naskah Akademik Rancangan Undang-Undang Pemilu, disampaikan Dalam Konsultasi Publik Kodifikasi Undang-Undang Pemilu, Pembaharuan Desain Penegakan Hukum Pemilu, Kerjasama Sekretariat Bersama Kodifikasai Undang-Undang Pemilu dengan Pusat Studi Konstitusi (PUSaKO) Fakultas Hukum Universitas Andalas, Padang 10 Juni 2016.

Widodo, Bambang Eka Cahya, Pemilu: Tanggung Jawab Kita Bersama, Jurnal Ultimatum, Volume 1 Nomor 1, Agustus 2008, Jakarta: STIH Iblam.

240 - Jurnal Cita Hukum. Vol. 4 No. 2 Desember 2016. P-ISSN: 2356-1440. E-ISSN: 2502-230X 